\title{
Mining Community Empowerment (A Study in Mine-Producing Areas of East Java Province, Indonesia)
}

\author{
Muhammad Lukman Hakim \\ Lecturer at Brawijaya University Faculty of Social and Political \\ Science \\ Secretary at the Research and Civil Service at the Faculty of \\ Social and Political Science \\ Brawijaya University \\ Malang, Indonesia \\ em.lukman79@ub.ac.id
}

\author{
Sihabudin \\ Faculty of Law, Brawijaya University \\ Malang, Indonesia \\ sihab@ub.ac.id
}

\begin{abstract}
East Java is a province rich of oil and gas resources with total reserves of 249,19 million barrels of oil and 4,32 TCF of gas. Some oil and gas mining companies operating in large scales in the area of East Java, among others are; Exxon Mobil Oil, Pertamina, Santos, Petrochina, and Indo-Pacific. This research was conducted in Sumenep Regency East Java province of Indonesia. The purpose of this research is to identify the role of oil and gas companies in relation to communityempowerment and poverty reduction as well as economic prosperity because the condition of the communities living near mining areas is still underdeveloped. This study employed observational techniques of active participation. By using descriptive qualitative research obtained through several techniques. Data collection techniques used by the researchers among others involved observations, interviews, documents and records. In analyzing the data, researchers used flow models.
\end{abstract}

Keywords---empowerment, community, corporate, mining.

\section{INTRODUCTION}

East Java is the province rich in oil and gas resources with total reserves of 249,19 million barrels of oil and 4,32 TCF of gas. Some oil and gas mining companies operating in large scales in the area of East Java, among others are; Exxon Mobil Oil, Pertamina, Santos, Petrochina, and Indo-Pacific. East Java is rich in oil and gas, as seen from the records of the Energy and Mineral Resources Ministry identifying there are 31 (thirty-one) blocks ready for exploitation, which certainly does not include blocks that have not yet been identified. According to plan, management of the 31(thirty-one) blocks will be or are already under the control of some oil and gas companies as described below;

TABLE 1.1 OIL AND Gas Companies OPERATING IN EAST JaVA

\begin{tabular}{|c|c|c|c|}
\hline Company & Block Name & Block Type & $\begin{array}{c}\text { Total } \\
\text { Blocks }\end{array}$ \\
\hline Pertamina EP & Jatim Area-4 & Onshore & 1 \\
\hline Pertamina EP & Jatim Area-2 & $\begin{array}{c}\text { Onshore and } \\
\text { Offshore }\end{array}$ & 1 \\
\hline PC Muria. LTD & Muriah & Offshore & 2 \\
\hline Sebana. LTD & Fur & Offshore & 1 \\
\hline $\begin{array}{c}\text { Amerada Hess } \\
\text { (Indonesia- } \\
\text { Pangkah). LTD }\end{array}$ & Pangkah & Offshore & 2 \\
\hline
\end{tabular}

\begin{tabular}{|c|c|c|c|}
\hline $\begin{array}{c}\text { Camar } \\
\text { Resources } \\
\text { Canada. INC } \\
\end{array}$ & Bawean & Offshore & 2 \\
\hline Pertamina EP & West Madura & Offshore & 4 \\
\hline $\begin{array}{c}\text { Job Pertamina- } \\
\text { Petrochina East } \\
\text { Java. LTD }\end{array}$ & Tuban & Onshore & 3 \\
\hline Pertamina EP & East Jatim Area-3 & Offshore & 1 \\
\hline $\begin{array}{c}\text { Santos } \\
\text { (Sampang) PTY. } \\
\text { LTD }\end{array}$ & Lacquer & Offshore & 1 \\
\hline $\begin{array}{c}\text { Knock Nemone. } \\
\text { LTD }\end{array}$ & NE. MADURA - II & Offshore & 1 \\
\hline $\begin{array}{c}\text { Santos (Madura } \\
\text { Offshore) PTY. } \\
\text { LTD } \\
\end{array}$ & $\begin{array}{c}\text { Madura Offshore } \\
\text { Block }\end{array}$ & Offshore & 1 \\
\hline $\begin{array}{c}\text { Huski Oil } \\
\text { (Madura) Ltd. }\end{array}$ & $\begin{array}{c}\text { Onshore and } \\
\text { Offshore Madura } \\
\text { Strait Area }\end{array}$ & $\begin{array}{l}\text { Onshore and } \\
\text { Offshore }\end{array}$ & 5 \\
\hline Pertamina ED. & Poleng & Offshore & 1 \\
\hline $\begin{array}{c}\text { South Madura } \\
\text { Exploration } \\
\text { Company } \\
\text { PTE.LTD }\end{array}$ & South Madura & $\begin{array}{l}\text { Onshore and } \\
\text { Offshore }\end{array}$ & 1 \\
\hline $\begin{array}{l}\text { Job. Pertamina } \\
\text { Medco Madura }\end{array}$ & $\begin{array}{l}\text { Onshore Madura } \\
\text { Island }\end{array}$ & Onshore & 1 \\
\hline $\begin{array}{l}\text { Conoco Philips } \\
\text { (Ketapang) LTD }\end{array}$ & Ketapang Block & Offshore & 1 \\
\hline $\begin{array}{l}\text { Knock Nemone. } \\
\text { LTD }\end{array}$ & NE. Madura - I & Offshore & 1 \\
\hline $\begin{array}{l}\text { EMP. Kangean } \\
\text { LTD }\end{array}$ & $\begin{array}{c}\text { Onshore and } \\
\text { Offshore Kangean }\end{array}$ & $\begin{array}{l}\text { Onshore and } \\
\text { Offshore }\end{array}$ & 4 \\
\hline $\begin{array}{c}\text { Anadarko } \\
\text { Petroleum } \\
\text { CORP } \\
\end{array}$ & NE. Madura - III & Offshore & 1 \\
\hline $\begin{array}{c}\text { Petronas } \\
\text { Carigali } \\
\text { Karapan LTD }\end{array}$ & $\begin{array}{l}\text { North East Madura } \\
\text { - IV }\end{array}$ & Offshore & 1 \\
\hline $\begin{array}{c}\text { Petronas } \\
\text { Carigali } \\
\text { Karapan LTD } \\
\end{array}$ & Karapan & Offshore & 2 \\
\hline $\begin{array}{l}\text { PT. Easco East } \\
\text { Throughout }\end{array}$ & East Throughout & Offshore & 1 \\
\hline $\begin{array}{l}\text { PT. Far East } \\
\text { Energy }\end{array}$ & East Kangean & Offshore & 1 \\
\hline $\begin{array}{l}\text { Lapindo Brantas } \\
\text { INC }\end{array}$ & Brantas & Offshore & 5 \\
\hline
\end{tabular}

Source; East Java Indonesian Environmental Forum -Walhi East Java, 2013. 
Until the year of 2018 there are 17 (seventeen) companies conducting exploration and exploitation of oil and gas in the development area of Madura as listed in the following:

1. Bawean Block Operator: Camar Resources Canada Inc. Contractors: Kerr-McGee of Indonesia Inc. (USA).

2. Bulu Block Operator: Pearloil Satria Ltd (United Arab Emirates) Contractor: Sebana Ltd.

3. Pangkah Block Operator: Amerada Hess IndonesiaPangkah Ltd. (USA) Contractor: Premier Oil Pangkah Ltd.

4. Onshore and Offshore Madura Strait Area Block Operator: Husky Oil (Madura) Ltd. Contractor: Hudbay Oil International Ltd (UK).

5. Karapan Block Operator: Amstelco Karapan Pte Ltd (UK) Contractor: Amstelco Karapan Pte Ltd East Bawean I block Operator: East Bawean.

6. East Bawean I Block Operator: East Bawean Ltd. (Canada) Contractor: CJSC Sintezmorneftegaz (Russia).

7. South East Madura Block Operator: PT Energy Minerals Lasting Contractor: PT Energy Minerals Lasting.

8. East Bawean II Block Operator: Bawean Husky Oil Ltd. (Canada) Contractor: Bawean Husky Oil Ltd.

9. North East Madura III Block Operator: Anadarko Indonesia Company (USA) Contractor: Anadarko Indonesia Company.

10. Madura Offshore Block Operator: Santos Madura Offshore Pty Ltd Contractor: Talisman Madura Ltd (Canada).

11. Mandala Block Operator: PT Bumi Hasta MuktiFortune Empire Group Ltd Contractor: Consortium of PT Bumi Hasta Mukti-Fortune Empire Group Ltd.

12. West Madura Block Operator: Kodeco Korea (May 6th 1981-6 May 2011), Pertamina (May 7th 2011-7 May 2031). Contractor: Kodeco Energy Company Ltd (1981-6 May 6 May 2011), Pertamina (May 7th 2011-7 May 2031).

13. North Madura Block Operator: Australian Worldwide Exploration Consortium North Madura Madura NZ Ltd.-North Energy Ltd. Contractor: Consortium Australian Worldwide Exploration NZ Ltd North North Madura Madura Energy Ltd.

14. Ketapang Block Operator: Petronas Carigali Ketapang II Ltd (Malaysia) Contractor: Gulf Resources Ketapang (Conoco Phillips-USA).

15. Coral Block Operator: Australian Worldwide Exploration Coral NZ Ltd Contractor: Australian Worldwide Exploration Coral NZ Ltd.

16. South Madura Block Operator: South Madura Exploration Company Pte Ltd Contractor: PT Eksindo South Madura.

17. Madura Block Operator: Society of Petroleum Engineers Petroleum Ltd (China) Contractor: Society of Petroleum Engineers Petroleum Ltd.

Figure 1.1 Project Location Map OF OIL AND GaS In MAdura ISLAND

The map in the picture above shows locations of oil and natural gas projects on the Madura Island. The north coast of East Java, including the island of Madura, is the center of oil and gas exploitation. The regions involved range from Tuban,
Gresik, Lamongan, Bojonegoro, Bangkalan, Pamekasan to Sumenep, but approximately $20-35 \%$ of the population live

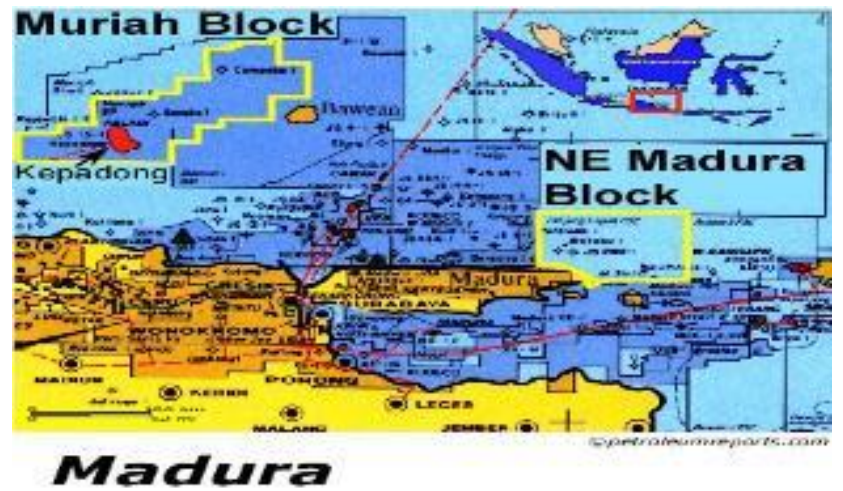

below the poverty line. Especially in Sampang regency, more than $35 \%$ of the population lives below the poverty line. It is completely in contrast with areas in the South shore such as; Blitar, Malang, Lumajang, Jember, Banyuwangi in which only $15-20 \%$ of the population lives below the poverty line.

To identify the role of oil and gas companies above in relation to community empowerment and poverty alleviation as well as economic prosperity, seeing the impacts caused is required. How the presence of these companies have significant contributions to the fundamental livelihoods of communities living near the mining areas. Nevertheless, this statement can be seen from the conditions of the Madura Island communities living near mining areas being underdeveloped despite the abundance of oil and gas in the territory.

\section{DISCUSSION}

The previous data shows the on-shore and off-shore areas of Sumenep Regency, one of the Regencies in Madura Island, many oil and gas companies, be it local nor international ones have explored natural gas in the area. Some of the companies, among others are; PT. Arbani (Arco Bali North Indonesia), Medco, Amoco, Beyond Petroleum (BP), Energi Mega Pratama Inc. (EMP), EMP Kangean Ltd. PT. Santos, and a Korean company namely Korea Knock Nemone Ltd. Since 1982 PT. Arbani has conducted exploration in Kangean Sumenep. The name "Arbani" was used due to the company's opinion that the islands rich in oil and natural gas were administratively a part of North Bali. After making sure oil and gas were located in the island of Terang, Sakala, Igangan, Sirasun I, Sirasun II, a year later in 1985 PT. Arbani sold 40\% of their shares to Beyond Petroleum (BP). Around the beginning of 1985 PT. Arbani and BP conducted drilling on the Pagerungan-1 Block and following that, drillings at Pagerungan Blocks 2, 3, 4, and 5. In February 1988, PT. Arbani also conducted exploration in West Kangean-1 Block and found gas reserves. Then, in a sustainable manner, it also found West Kangean Block 2 and 3. In 1993, PT. Arbani found new gas reserves in Sirasun-1 Block, Apprasial Block (Sirasun-2). Also, this year PT. Arbani is conducting a 3Dimensional Siesmic Survey in the Blocks of Terang, Sirasun, and Batur.

Many oil and gas companies are coming to this Regency of 127 (one-hundred twenty seven) islands. Starting from the oil and gas company namely Korea Knock Nemone Ltd., Ever since the year of 2005 occupied Wulan I and Wulan II Blocks 
in the waters of Dungkek and Pasongsongan sub-disctricts in Sumenep Regency. Santos Oyong Australia occupies Maleo I and II Blocks in the waters of Gili-Raja in the Gili-Genting sub-district, Sumenep Regency which is the second largest oil and natural gas reserves after Kangean. Even since 2006, the Malaysian government-owned enterprise (Petronas) has signed a contract to manage a block of oil and natural gas in the waters of Podai, Sumenep Regency. In order to simplify, the author has provided the information in a table.

TABle 1.2 List OF OIL AND NATURAL Gas CoMPANIES IN SuMENEP

\begin{tabular}{|c|c|c|c|c|}
\hline No. & $\begin{array}{c}\text { Company } \\
\text { name }\end{array}$ & Year & Area contract & Information \\
\hline 1. & PT. Arbani & 1982 & Kangean Block & $\begin{array}{l}\text { Kangean is an } \\
\text { island in the } \\
\text { Sumenep Regency } \\
\text { distanced from the } \\
\text { Kalianget port, } \\
\text { Sumenep by } 12 \\
\text { hours of travel by } \\
\text { the sea. }\end{array}$ \\
\hline 2. & PT. Arbani & 1984 & $\begin{array}{l}\text { Terang, Sakala, } \\
\text { Igangan, } \\
\text { Sirasun I, } \\
\text { Sirasun II. }\end{array}$ & \\
\hline 3. & $\begin{array}{l}\text { PT. Arbani } \\
\text { and BP }\end{array}$ & 1985 & $\begin{array}{l}\text { Pagerungan } \\
\text { Blocks } 1,2,3,4,5\end{array}$ & \\
\hline 4. & $\begin{array}{l}\text { PT. Arbani } \\
\text { and BP }\end{array}$ & 1988 & $\begin{array}{l}\text { West Kangean } \\
\text { block } 1,2,3\end{array}$ & \\
\hline 5. & $\begin{array}{l}\text { PT. Arbani } \\
\text { and BP }\end{array}$ & 1993 & $\begin{array}{l}\text { Sirasun Block- } \\
\text { 1, Apprasial } \\
\text { Block (Sirasun- } \\
\text { 2) }\end{array}$ & $\begin{array}{l}\text { Conducted 3D } \\
\text { Siesmic survey in } \\
\text { the Blocks of } \\
\text { Terang, Sirasun, } \\
\text { and Batur. }\end{array}$ \\
\hline 6. & BP-Amoco & 1998 & & $\begin{array}{l}\text { Shares of PT. } \\
\text { Arbani were taken } \\
\text { over by BP and } \\
\text { collaborated with } \\
\text { Amoco to become } \\
\text { BP- Amoco }\end{array}$ \\
\hline 7. & $\begin{array}{l}\text { BP-Kangean } \\
\text { Ltd. }\end{array}$ & 2000 & & $\begin{array}{l}\text { PT. Arbani } \\
\text { rejoined into BP } \\
\text { BP-Amoco- } \\
\text { Kangean Ltd. }\end{array}$ \\
\hline 8 & $\begin{array}{l}\text { EMP- } \\
\text { Kangean } \\
\text { Ltd. }\end{array}$ & 2004 & $\begin{array}{l}33 \text { Islands in } \\
\text { Kangean and } \\
\text { Sapeken, } \\
\text { Sumenep } \\
\text { Regency }\end{array}$ & $\begin{array}{l}\text { BP-Kangean Ltd } \\
\text { was bought by } \\
\text { Energi Mega } \\
\text { Pratama Ltd. } \\
\text { became EMP- } \\
\text { Kangean Ltd. }\end{array}$ \\
\hline 9. & $\begin{array}{l}\text { Korea } \\
\text { Knock } \\
\text { Nemone } \\
\text { Ltd. }\end{array}$ & 2005 & $\begin{array}{l}\text { Wulan Block I, } \\
2\end{array}$ & $\begin{array}{l}\text { In the waters of } \\
\text { Dungkek and } \\
\text { Pasongsongan sub- } \\
\text { districts in } \\
\text { Sumenep Regency }\end{array}$ \\
\hline 10. & $\begin{array}{l}\text { Korea } \\
\text { Knock } \\
\text { Nemone } \\
\text { Ltd. } \\
\end{array}$ & 2005 & $\begin{array}{l}\text { East Madura } \\
\text { Block I }\end{array}$ & $\begin{array}{l}\text { Waters of } \\
\text { Dungkek and Raas } \\
\text { Island, Sumenep } \\
\text { Regency. }\end{array}$ \\
\hline 11. & $\begin{array}{l}\text { Santos } \\
\text { Oyong } \\
\text { Australia }\end{array}$ & 2005 & $\begin{array}{l}\text { Maleo Block } \\
1.2\end{array}$ & $\begin{array}{l}\text { In the waters of } \\
\text { Gili Raja, Gili } \\
\text { Genting Sub- } \\
\text { District and } \\
\text { Talango in the } \\
\text { Sumenep Regency } \\
\text { as the second } \\
\text { largest oil and } \\
\text { natural gas block } \\
\text { after Kangean. }\end{array}$ \\
\hline 12. & $\begin{array}{l}\text { Petronas } \\
\text { Malaysia }\end{array}$ & 2006 & Podai Block & $\begin{array}{l}\text { Podai waters, } \\
\text { Sumenep Regency }\end{array}$ \\
\hline
\end{tabular}

Source: compiled from various sources
The flow of natural gas to consumers since $31^{\text {st }}$ January 1994 through the 28-inched undersea pipeline with a length of 360 kilometers $(\mathrm{km})$ and $70 \mathrm{~km}$ on-shore pipe line with a cargo of 175 MMCFD, EMP Kangean Ltd. has transmitted the natural gases to following places: (1) PLN Gresik 3 as much as 168.500 MCF with an average of 117.352 MCFD; (2) Petrokimia Gresik an amount of $226.400 \mathrm{MCF}$ with an average of $7606 \mathrm{MCFG}$; (3) National Gas Company in Porong, Sidoarjo with an amount of $17.800 \mathrm{MMCF}$ with the average of 659 MCFD. The flow towards the three companies as stated above is pegged at $\$ 1.78$ (US Dollars) per MMBTU at the wellhead. Meanwhile, the number of gas wells that have been drilled amounts to 9 out of 16 that has been planned beforehand. The previous can be seen in the following data:

Figure 1.2 NATIONAL GAS PIPELINE NETWORK

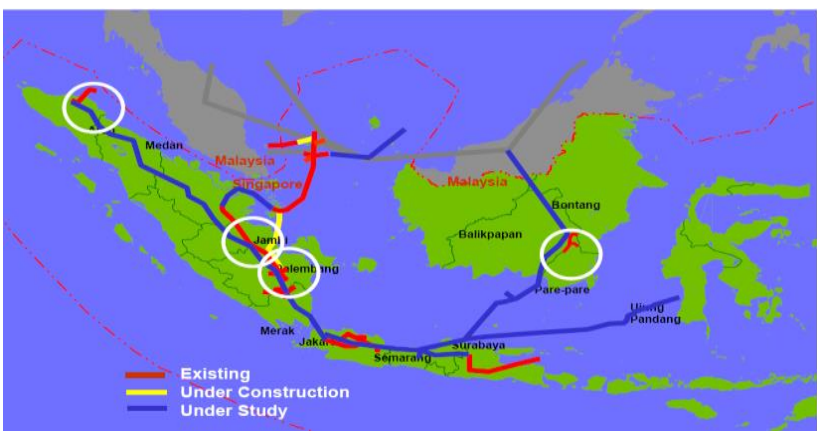

Source; National Oil and Gas Industry Fixed Guidelines and Patterns 2005-2020, Blueprint Implementation of Law No. 22 of 2001 concerning Oil and Gas, Ministry of Energy and Mineral Resources.

FiguRE 1.3 INDONESIAN GAS PIPELINE IndOIIASIA Integrated Gas Transmission Pipellines

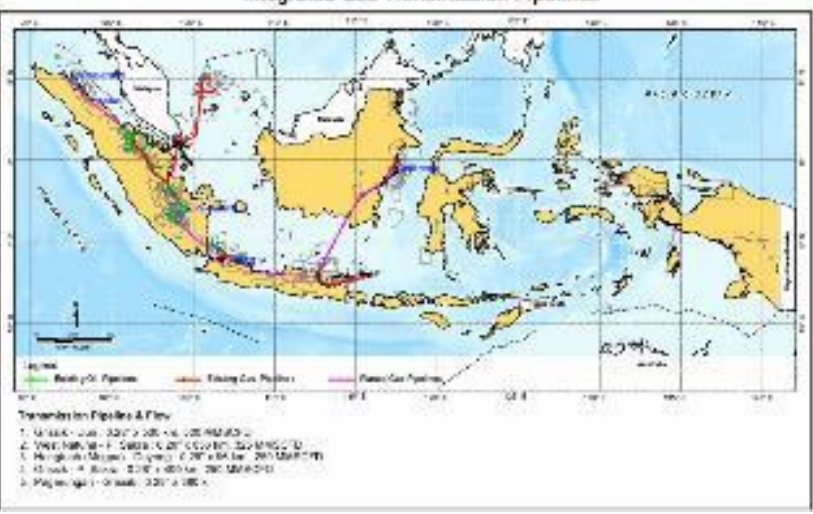

Source; National Oil and Gas Industry Fixed Guidelines and Patterns 2005-2020, Blueprint Implementation of Law No. 22 of 2001 concerning Oil and Gas, Ministry of Energy and Mineral Resources.

Based on the results of the oil and gas exploitation that has been conducted by the above-mentioned company since 1982, gas companies operating on the island of Pagerungan Besar were able to build a gas facility management with the capacity of 2x175 million cubic feet of natural gas per day. Condensate storage facilities (Single Point Mooring System) with a capacity of 125,000 tons dwt is completed with a 2.5 $\mathrm{Km}$ loading pipeline system to the Pagerungan gas field pipeline system. Other infrastructures that has been built in the area amount to a quarter more than the total island area of Pagerungan Besar, among others; pavilion, planes bases, 
roads, and other facilities for oil and gas companies. The following is an aerial photography of a gas refinery in Sumenep Kangean island, which occupies almost all available island areas.

FIGURE 1.4 GAS REFINERY IN KANGEAN ISLAND, SUMENEP REGENCY

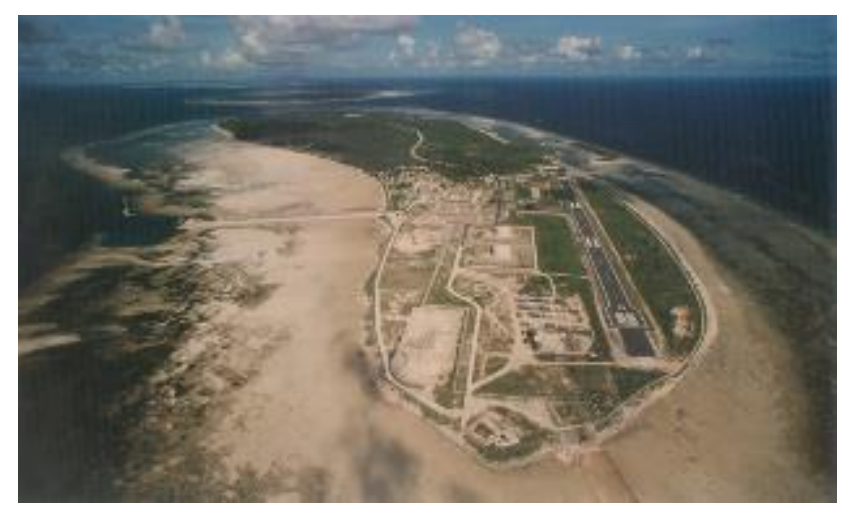

Source; EMP-Kangean Ltd. Progress Report

In reality, the beneficial outcome of the natural gas exploitation in the afore-mentioned Kangean block area until now could not be enjoyed by the communities that live near the mining area. Electricity is only available to people who live on the island of Kangean and Sapeken, yet the availability is also limited from 05.00 PM until 07.00 PM, whereas in the meantime several other smaller islands around Kangean and Sapeken which have been the natural gas fields such as, Pagerungan Besar, Pagerungan Kecil, Paliat, and Sepanjang until now have never used electricity. It is an ironic reality if seen from the results of the natural gas used by these companies. Out of 6 (six) production wells, PGA 1 , 2,3,4 and PGB 1,2 have been able to produce 200 million cubic feet per day. Even the exploitation result of this gas has already peaked with great figure which is approximately 334 million cubic feet per day.

Based on the description above, the real conflicts within the community living around the mine are economic and social inequalities experienced and by the absence of legal remedies capable of solving the ongoing problems, resulting in helpless communities living among the abundance of oil and natural gas, as compared with other areas in East Java that do not rely on mining oil and gas.

Local mining community empowerments are often done with the presence of many operating oil and gas companies, in the context of this discussion it is not merely empowering the community living near the mine alone, but it must also be based on justice for the community. The compensation funds for exploitation is done by administering funds for the community, later known as Community Development Funds from the development around the mining areas, community development funds issued by the Mining Company accepted by the society are merely related to a physical development whereas the community around the mine area remains dependent.

\section{MINING COMMUNITY EMPOWERMENT}

The term "empowerment" is often equated with poverty reduction in various projects to reduce the number of people living in poverty. In the context of empowerment, development is often associated with the activities of public participation in the process of determining the grants or financial aid given to the village or district level. Public participation in determining whether the aid would be used to build a road or a bridge is believed to be a process to empower communities.

The most recent development approach that emphasizes the public participation is believed to be able to reduce poverty compared to giving financial aid in a top-down concept without a public dialogue process, which then creates and develops the concept and theory of empowerment, rights relation in the effort to reduce poverty.

Empowerment is the process of increasing the capacity of a person or group in determining how to perform the desired action or output. Empowerment is a combination of two interrelated factors which are: agency and the opportunity structure. Agency is defined as an ability of a person to decide a choice that is significant to him/her. Whereas, the opportunity structure is the various aspects that could make a person do something because of the ability to choose. Hence, the empowerment can be defined as a situation when there is an imbalance of power relations, then someone who has enough capacity could perform effective decisions and can take advantage from various efforts/projects to suppress poverty rate.

Approach to development and poverty reduction through empowerment is closely connected with the so-called rightsbased approach or RBA. RBA concept is based on the idea that every person who has a variety of fundamental rights, where every state is obliged to promote, improve, and protect the rights of its citizens. The rights in general, can be interpreted as a legitimate claim against a number of persons, groups or organizations such as social or economic institutions, a country, or an international community. They are required to meet the demands of rights holders. In the context of development and efforts to reduce poverty, human rights can be interpreted as a "power relation," where the state must fulfill the rights of its citizens,

Human rights are related to poverty, the relevance of freedom, human rights and development. By incorporating the concept of rights, the ability (and capacity), opportunity, liberty, and individual rights into the discourse of poverty, then poverty can be categorized as a contradiction to fundamental human rights [1].

Related to this research, mining management is often a problem faced by East Java provincial government in the form of:

1. Land disputes;

2. Environmental degradation; and

3. Social and economic inequality.

The empowerment of local mining communities is an attempt to improve the quality of the communities living around the mine so as to catch up in the field of life, hence normative arrangements of that is necessary.

Local mining community empowerment which has been carried out is the object of criticism of this research by treating critically the legal principles of mining exploitation along with projection methods and scenario construction. 
With its autonomous character, it is believed that the law can control repression and maintain its own integrity. Law is a tool for humans. It is an instrument to serve human needs. In this sense, the isolation of the legal system from the various social institutions around it, in fact, has a bad impact in terms of human needs themselves. Law, easily transforming into a self-serving institution, is no longer serving humans. Law can no longer be relied upon as a tool of change and as a tool to achieve substantive justice. The result is clear, the social legitimacy of the law has dropped sharply [2]. The danger sign of the erosion of the authority and the stagnation of substantive justice have become the focus of criticism of the law.

Actually, under the legal autonomy doctrine, the status quo ideology is hidden. And the status quo itself is a canopy or a protection fortress for the rich. This is the first point of criticism by Neo-Marxists. The biased law is very clear. It benefits the rich yet harms and deceives the poor. By doing so, legal institutions have been unnoticeably polluted, and it has contributed to the lack of social order in general. It works as a tool of power. The second point that was criticized by Neo-Marxist is liberal legalism, particularly regarding the idea that the purpose of justice can be achieved through a system of rules and procedures that are objective, impartial, and autonomous. According to Neo-Marxists, factually, the rule of law is not able to overcome the fundamental issues of social justice. Even worse, the rule of law is a "hidden enemy" of social justice itself. Not social justice achieved in the rule of law, but victory for the rich. The court is not the place where the lower class society gets social justice, but it becomes the platform for the upper classes to judge those of the lower classes [3].

In the midst of the series of criticisms on the legal authority crisis, Nonet-Selznick proposes a responsive [4] legal model by giving special attention to variables related to law which consist of: the role of coercion in law, the relationship between law and politics, the state, moral order, place of discretion, role of purpose in legal decisions, participation, legitimacy, and conditions of compliance with the law. Social change and social justice require a responsive legal order. This need, in fact, has become the main theme of all experts who agree with functional, pragmatic, and purposive (goal-oriented) spirit, as well as Roscoe Pound, adherents of legal realism, and contemporary critics. The model of rules proposed by Dworkin, can no longer be relied upon to handle the dynamics of social needs in the midst of change.

Through this model, Nonet and Selznick put the law as a means of response to the provisions of social and public aspirations which are open by nature. This law emphasizes the type of accommodation to accept social changes in order to achieve justice and public emancipation. Concern to accommodate social aspirations causes this theory to be classified in the area of sociological jurisprudence, that is, a philosophical approach to law that emphasizes sociallyrelevant legal design efforts.

Government Regulation No. 47 year 2012 on Corporate Social and Environmental Responsibility of Limited Liability Companies in Indonesia is a venture of sustainable development in mining areas. The rule asserts that social responsibility and environmental mining companies are as institutional responsibility, and they are formally bound with the applicable laws (mandatory) and are not an interactional responsibility which is voluntary.

Under these provisions, the mining company must implement a program of social responsibility and environmentally sustainable company if they want their business to proceed because, on one hand, the social and environmental responsibility has become a requirement for mining companies to gain support from the people living around the mining site. Therefore, there is no legal reason for mining companies in Indonesia to refuse to implement the social and environmental responsibility in its business activities.

Social responsibility and the environment, especially for mining companies under Government Regulation No. 47 year 2012 on Corporate Social and Environmental Responsibility of Limited Liability Companies in Indonesia are deeply encouraged to ensure the guarantee of the environmental damage recovery, so that it is expected that there will be a balance between profit, environment and society. However, there are differences in the understanding of the contradictory implementation of CSR in Indonesia, in which one side that is interactional and voluntary and, on the other hand, is institutional in nature, which is formally bound to the laws and regulations. This raises the pros and cons concerning that the implementation of CSR in the mining sector is a dual system in nature.

Sumenep Regency as an area that has a relatively unique number and area, consisting of 126 islands separated from Madura Island as its main island, the northernmost island, Karamian Island, located in Masalembu District with a distance of approximately 151 nautical miles from Kalianget Port. The distance from Kalianget Port to the island is about 15 hour drive, further than the trip from Sulawesi Island which is only 3 hours away. Meanwhile the easternmost island is Sakala Island with a distance of approximately 135 nautical miles from the Kalianget Port or about 12 hour drive, whereas from the island of Bali it is only 4 hours away. Therefore, socio-economically, people depend more on other islands nearby rather than on Sumenep Regency itself.

Sumenep Regency is a part of East Java Province, precisely at the eastern end of Madura Island and is located northeast of the capital of East Java Province (Surabaya City). Geographically, Sumenep Regency is located between $113^{\circ} 3254 "$ " $116^{\circ} 1648^{\prime \prime}$ East Longitude and $4^{\circ} 5500 "-7^{\circ} 24$ 00" South Latitude. The distance between Sumenep Regency and the Capital City of East Java Province (Surabaya City) is approximately $200 \mathrm{Km}$, whereas the distance is a sum of additional distance for crossing the Madura Island and the Madura Strait. The administrative boundaries of Sumenep Regency are as follows:

$\begin{array}{lll}\text { - } & \text { North } & \text { : Java sea } \\ \text { - } & \text { West } & \text { : Pamekasan } \\ \text { - } & \text { Soust } & \text { : Java Sea / Flores Sea } \\ \text { Th } & \text { : Madura Strait }\end{array}$

The geography consists of lands and islands with a total area of $2093.46 \mathrm{~km} 2$. The regional divisions are as follows: 
- The land area as the wider area of the archipelago with an area of $1146.93 \mathrm{~km} 2$ or $54.79 \%$ of the overall Sumenep, consisting of 18 (eighteen) districts on the island of Madura and islands in the District of Dungkek.

- The islands have a wide area of $946.53 \mathrm{~km} 2$ or $45.21 \%$ of the total area of Sumenep. The number of islands is 126 islands, consisting of 48 inhabited islands, 78 uninhabited island, 104 named islands and 22 nameless islands.

- The islands consist of 9 (nine) districts, namely: Giligenting, Talango, Nonggunong, Gayam, Ra'as, Arjasa, Sapeken, Kangayan and District Masalembu.

Meanwhile, data in 2011 showed that the population of Sumenep District was $1,042,312$ people with a sex ratio of 90.75. This shows that every 100 inhabitants there are 91 to 92 men, which means the growth of female population is more than that of men. Whereas, the Population Vulnerability Ratio accounted for 81.81 , meaning that every 100 working population, 81 to 82 people are employed, hence Sumenep has a low vulnerability ratio.

TABLE 3.3 POPULATION RATIO IN SUMENEP REGENCY

\begin{tabular}{|c|c|c|c|c|c|}
\hline \multirow[b]{2}{*}{ No. } & \multirow{2}{*}{$\begin{array}{l}\text { Age } \\
\text { range } \\
\text { (years) }\end{array}$} & \multicolumn{2}{|c|}{ Population } & \multirow[b]{2}{*}{ Source } & \multirow[b]{2}{*}{ Information } \\
\hline & & Male & Female & & \\
\hline 1 & $0-14$ & $\begin{array}{l}148 \\
769\end{array}$ & 163925 & BPS & \multirow{3}{*}{$\begin{array}{l}\text { The productive } \\
\text { age is between } \\
15-55 \text { years of } \\
\text { age where } \\
\text { people are able } \\
\text { to work. }\end{array}$} \\
\hline 2 & $15-55$ & $\begin{array}{l}272 \\
743\end{array}$ & 300529 & BPS & \\
\hline 3 & $56+$ & $\begin{array}{l}74 \\
384\end{array}$ & 81962 & BPS & \\
\hline \multicolumn{2}{|c|}{ Sub-Total } & $\begin{array}{l}495 \\
896\end{array}$ & 546416 & & \\
\hline \multicolumn{4}{|c|}{ Population Total } & 1042312 & \\
\hline \multicolumn{4}{|c|}{ Sex ratio (male / female) x 100} & $\begin{array}{l}90.7542 \\
9709\end{array}$ & Women > Men \\
\hline \multicolumn{4}{|c|}{$\begin{array}{l}\text { Population Vulnerability Level } \\
\text { Ratio (Productive Age / non- } \\
\text { productive) x100 }\end{array}$} & $\begin{array}{l}81.8180 \\
5495\end{array}$ & Low \\
\hline \multicolumn{4}{|c|}{ Total Productive Age } & \multicolumn{2}{|l|}{573272} \\
\hline \multicolumn{4}{|c|}{ Total Non-Productive Age } & \multicolumn{2}{|c|}{469040} \\
\hline \multicolumn{4}{|c|}{ Vulnerability ratio } & \multicolumn{2}{|c|}{81.81805495} \\
\hline
\end{tabular}

Source: Adapted from Sumenep in Numbers, Year of 2012

The largest job opportunity in Sumenep Regency is trade and commerce due to the rapid development of the tourism sector in Sumenep.

TABLE 3.4 FIELD OF WORK

\begin{tabular}{|l|l|l|l|}
\hline No. & \multicolumn{1}{|c|}{ Field of work } & \multicolumn{1}{c|}{ Amount } & \multicolumn{1}{c|}{$\begin{array}{c}\text { Data } \\
\text { source }\end{array}$} \\
\hline 1 & Agriculture & 93.149 & BPS \\
\hline 2 & Mining & 3.715 & BPS \\
\hline 3 & Industrial Management & 45.705 & BPS \\
\hline 4 & Electricity, Gas, and Water & 2.586 & BPS \\
\hline 5 & Building / Construction & 7.664 & BPS \\
\hline 6 & Trading and Commerce & 110.923 & BPS \\
\hline 7 & Transport / Transportation & 35.172 & BPS \\
\hline 8 & Services & 9.216 & BPS \\
\hline 9 & Finance and Banking & 11.144 & BPS \\
\hline \multicolumn{2}{|l|}{ Source: Adapted from Sumenep in Numbers, Year of 2012 } \\
\hline
\end{tabular}

The general unemployment rate in the last 3 years decreased in line with the development of Sumenep Regency. In 2009 the unemployment rate of high school graduates was very high but in the following year 2010 it dropped dramatically. The phenomenon had been evaluated by the government in 2010 to increase the use of labor from high school graduates. In 2011, high school graduates accounted for the highest unemployment.

TABLE 3.5 UNEMPLOYMENT RATE

\begin{tabular}{|l|l|l|l|l|}
\hline \multirow{2}{*}{ No. } & \multicolumn{2}{|}{ Unemployment Rate } & \multicolumn{3}{|c|}{ Amount } \\
\cline { 3 - 5 } & & \multicolumn{1}{|c|}{2009} & $\mathbf{2 0 1 0}$ & $\mathbf{2 0 1 1}$ \\
\hline 1 & Not finished Primary School & 16704 & 12298 & 7,700 \\
\hline 2 & Elementary School & 52662 & 10,620 & 6.823 \\
\hline 3 & Junior High School & 58306 & 9503 & 9.961 \\
\hline 4 & High School / Vocational School & 131 & 7826 & 16.773 \\
& & 802 & & \\
\hline 5 & Diploma / University & 75052 & 12.297 & 11094 \\
\hline \multicolumn{4}{|c|}{ Source: Adapted from Sumenep in Numbers, Year of 2012 }
\end{tabular}

The data on places of worship is based on spiritual activities. The growth rate of Islamic worship houses increases every year due to the population growth and the desired decisions of religious leaders to build more, quite on the contrary to the Churches, as due to the decreasing number of Christians in the area.

TABLE 3.6 PLACES OF WORSHIP

\begin{tabular}{|l|l|l|l|l|}
\hline No. & \multicolumn{1}{|c|}{ Worship Place } & \multicolumn{1}{|c|}{2009} & $\mathbf{2 0 1 0}$ & \multicolumn{1}{|c|}{$\mathbf{2 0 1 1}$} \\
\hline 1 & Mosque & 1435 & 1441 & 1502 \\
\hline 2 & Church & 1 & 1 & 1 \\
\hline 3 & Temple & na & na & na \\
\hline 4 & Monastery & na & na & na \\
\hline 5 & Others & na & na & na \\
\hline
\end{tabular}

Source: Adapted from Sumenep in Numbers, Year of 2012

In majority, primary school is the highest education degree earned by the locals in addition to the fact that high school infrastructures are rare in the village, and informal educational institutions such as islamic dormitories of Salafiah are developed in the Regency of Sumenep

TABLE 3.7 EDUCATION LEVEL

\begin{tabular}{|l|l|l|l|l|}
\hline No. & \multicolumn{1}{|c|}{ Level } & amount & $\begin{array}{c}\text { Data } \\
\text { source }\end{array}$ & Information \\
\hline 1 & Pre-School & na & BPS & \\
\hline 2 & Kindergarten & 372 & BPS & \\
\hline 3 & Primary School & 1192 & BPS & \\
\hline 4 & Junior High School & 350 & BPS & \\
\hline 5 & $\begin{array}{l}\text { High School / Vocational } \\
\text { School }\end{array}$ & 163 & BPS & \\
\hline 6 & Academy & na & BPS & \\
\hline 7 & University & 4 & BPS & \\
\hline
\end{tabular}

Source: Adapted from Sumenep in Numbers, Year of 2012

In general, the development of health facilities is improving. At this time what needs to be improved is the Puskesmas (public health center) facility which continues to increase every year, the Pusyandu (pre- and post-natal healthcare and information) also needs to be improved. And the main thing in health improvement is that health programs for the poor are still lacking attention. Many poor people cannot gain access to health despite the government programs.

TABle 3.8 HeAlth Facilities

\begin{tabular}{|l|l|l|l|l|}
\hline No. & \multicolumn{1}{|c|}{ Facility } & \multicolumn{1}{|c|}{2009} & \multicolumn{1}{|c|}{2010} & \multicolumn{1}{c|}{$\mathbf{2 0 1 1}$} \\
\hline 1 & Regional Public hospital & 1 & 1 & 3 \\
\hline 2 & Private Hospital & na & na & na \\
\hline 3 & Maternity Clinic & 4 & 4 & 335 \\
\hline 4 & Pharmacy & 14 & 14 & 14 \\
\hline
\end{tabular}




\begin{tabular}{|l|l|l|l|l|}
\hline 5 & Doctor's Clinic & na & na & na \\
\hline 6 & PHC (Public Health Center) & 30 & 30 & 30 \\
\hline 7 & Subsidiary Health Center & 68 & 68 & 68 \\
\hline 8 & $\begin{array}{l}\text { Polindes (Village Maternity } \\
\text { Center) }\end{array}$ & 179 & 179 & 290 \\
\hline 9 & $\begin{array}{l}\text { IHC (Information Health } \\
\text { Centre) }\end{array}$ & 1352 & 1352 & 1401 \\
\hline \multicolumn{4}{|l|}{ Source: Adapted from Sumenep in Numbers, Year of 2012 } \\
\hline
\end{tabular}

The development of road infrastructure for the districts increases every year, but the provincial and state roads remain the same. Current issues related to the road infrastructures near oil and gas exploitation sites are extremely underdeveloped, and this triggers complaints from local communities.

TABLE 3.9 ROAD INFRASTRUCTURES

\begin{tabular}{|c|c|c|c|c|}
\hline No. & Variables & 2009 & 2010 & 2011 \\
\hline 1 & $\begin{array}{l}\text { The length of } \\
\text { provincial roads }\end{array}$ & $69600 \mathrm{Km}$ & $69600 \mathrm{Km}$ & $69600 \mathrm{Km}$ \\
\hline 2 & $\begin{array}{l}\text { The length of } \\
\text { district roads }\end{array}$ & $\begin{array}{l}1512304 \\
\mathrm{Km}\end{array}$ & $\begin{array}{l}1517134 \\
\mathrm{Km}\end{array}$ & $\begin{array}{l}1629900 \\
\mathrm{Km}\end{array}$ \\
\hline 3 & $\begin{array}{l}\text { The length of } \\
\text { State roads }\end{array}$ & $48830 \mathrm{Km}$ & $48830 \mathrm{Km}$ & $48830 \mathrm{Km}$ \\
\hline
\end{tabular}

Population of Sumenep Regency from year to year has experienced an increase, a growth rate of $10 \%$ on average per year. If there is no strategic plan from the government, then this will cause occupational issues, including the lack of job opportunities that leads to social conflict and crime. Based on information from the Department of Social Welfare, several Districts that have higher crime rate also have a higher rate of population and unemployment.

TABle 3.10 Population GROWTH RATE

\begin{tabular}{|l|l|c|c|c|}
\hline \multirow{2}{*}{ No. } & \multirow{2}{*}{ Population growth rate } & $\begin{array}{c}2007- \\
2008\end{array}$ & $\begin{array}{c}2009- \\
2010\end{array}$ & $\begin{array}{c}2011- \\
2012\end{array}$ \\
\hline 1 & Sumenep Regency & $0.39 \%$ & $0.39 \%$ & $0.38 \%$ \\
\hline \multicolumn{3}{|l|}{ Source: Adapted from Sumenep in Numbers, Year of 2012 }
\end{tabular}

There are no changes of the population growth rate in Sumenep Regency in the last three years, which is $0.39 \%$, however in 2011 - 2012, the growth rate of the population has decreased due to the government's family-planning program which proves effective. There are no links between the growth rate of the population with oil and gas, despite the activities on oil and Gas in Pagerungan. Sumenep was temporarily suspended.

\section{CONCLUSION}

Based on empirical data analysis it is known that in general the CD program in Sumenep Regency which is carried out by the KKKS is still as a "Charity" but has not yet led to Community Development. This is reinforced by the many grant-based assistance with very little community participation to plan, implement and monitor it, thus triggering conflicts caused by the differences in perceptions between the community and the KKKS.

TABLE 4.11 CSR PROGRAM IN SUMENEP REGENCY

\begin{tabular}{|c|l|l|l|}
\hline $\begin{array}{c}\text { ComDev } \\
\text { Program }\end{array}$ & $\begin{array}{c}\text { Company } \\
\text { (sample) }\end{array}$ & $\begin{array}{c}\text { Scope of } \\
\text { Community } \\
\text { Development } \\
\text { Program }\end{array}$ & $\begin{array}{c}\text { Program } \\
\text { Objectives }\end{array}$ \\
\hline Education & $\begin{array}{l}\text { PT } \\
\text { Santos \& }\end{array}$ & $\begin{array}{l}\text { Education } \\
\text { infrastructure }\end{array}$ & $\begin{array}{l}\text { Targets include } \\
\text { renovation of }\end{array}$ \\
\hline
\end{tabular}

\begin{tabular}{|c|c|c|c|}
\hline & HCML & $\begin{array}{l}\text { development } \\
\text { activities limited to } \\
\text { renovation of } \\
\text { buildings in } \\
\text { villages, covering } \\
\text { kindergartens, } \\
\text { Elementary / } \\
\text { Primary Schools/ } \\
\text { Madrasah and } \\
\text { middle schools }\end{array}$ & $\begin{array}{l}\text { buildings in the } \\
\text { village including } \\
\text { Kindergartens, } \\
\text { Elementary / } \\
\text { Primary Schools/ } \\
\text { Madrasah and } \\
\text { middle schools }\end{array}$ \\
\hline Health & $\begin{array}{l}\text { PT } \\
\text { Santos \& } \\
\text { HCML }\end{array}$ & $\begin{array}{l}\text { The provision of } \\
\text { clean water } \\
\text { infrastructure } \\
\text { includes the } \\
\text { manufacture of } \\
\text { spring water } \\
\text { protection (PMA), } \\
\text { drilling wells } \\
\text { (SBR), public } \\
\text { hydrants (HU), } \\
\text { piping systems, } \\
\text { digging wells, } \\
\text { rainwater storage } \\
\text { and bathing, } \\
\text { washing and toilet } \\
\text { facilities. }\end{array}$ & $\begin{array}{l}\text { Targeted } \\
\text { programs aimed } \\
\text { at communities or } \\
\text { areas that lack } \\
\text { water, toilets or } \\
\text { latrines. }\end{array}$ \\
\hline Agriculture & $\begin{array}{l}\text { PT } \\
\text { Santos \& } \\
\text { HCML }\end{array}$ & $\begin{array}{l}\text { Rural area irrigation } \\
\text { development is } \\
\text { prioritized in } \\
\text { network } \\
\text { rehabilitation, } \\
\text { improving rural } \\
\text { irrigation, new rural } \\
\text { irrigation } \\
\text { development. }\end{array}$ & $\begin{array}{l}\text { Objective of the } \\
\text { program is aimed } \\
\text { at the agricultural } \\
\text { land surrounding } \\
\text { the oil and gas } \\
\text { exploitation site. }\end{array}$ \\
\hline Environment & $\begin{array}{l}\text { PT } \\
\text { Santos \& } \\
\text { HCML }\end{array}$ & $\begin{array}{l}\text { Development of } \\
\text { Street-lighting } \\
\text { facilities }\end{array}$ & $\begin{array}{l}\text { Programs for the } \\
\text { poor }\end{array}$ \\
\hline economy & $\begin{array}{l}\text { PT } \\
\text { Santos \& } \\
\text { HCML }\end{array}$ & $\begin{array}{l}\text { Development of } \\
\text { village markets and } \\
\text { fish auction centers. }\end{array}$ & $\begin{array}{l}\text { Program targets } \\
\text { rural markets and } \\
\text { fish auction } \\
\text { centers. }\end{array}$ \\
\hline
\end{tabular}

Source: Adapted from various sources, Year 2012-2014

Mining companies in East Java must implement corporate social and environmental responsibility programs if they want to be sustainable business because social and environmental responsibility has become a necessity for mining companies to get support from the people who live around the mining site. Therefore, there is no legal reason for mining companies in Indonesia not to carry out social and environmental responsibilities in their business activities.

\section{REFERENCES}

[1] Amartya Sen, Development As Freedom (New York: Anchor Bookss), 1999..

[2] S. Rahadjo, Law and Social Change: A Theoretical Review and Experiences in Indonesia, Bandung, Alumni, 1983..

[3] Empowerment team, Poverty Reduction and Economic Management (PREM) Group, World Bank, 2010.

[4] B. L. Tanya, Law Theory, Bandung: Alumni, 2007.

[5] Empowerment team, Poverty Reduction and Economic Management (PREM) Group, World Bank, 2010..

[6] B. L. Tanya, Teori Ilmu Hukum, Bandung, Alumni., Bandung. 